Terra Nova

April 2015, Volume 27 Issue 2 Pages 122-129

Achimer

http://dx.doi.org/10.1111/ter.12139

http://archimer.ifremer.fr/doc/00253/36466/

(C) 2015 John Wiley \& Sons Ltd

\title{
Sedimentary markers in the Provençal Basin (western Mediterranean): a window into deep geodynamic processes
}

\author{
Leroux Estelle ${ }^{1,2,{ }^{*}}$, Aslanian Daniel ${ }^{3}$, Rabineau Marina ${ }^{2}$, Moulin Maryline ${ }^{3}$, Granjeon Didier ${ }^{4}$, Gorini \\ Christian ${ }^{1}$, Droz Laurence ${ }^{2}$
}

${ }^{1}$ Univ Paris 06, UPMC, ISTEP, UMR 7193, F-75005 Paris, France.

2 IUEM UBO, CNRS, UMR6538, Domaines Ocean, F-29280 Plouzane, France.

3 IFREMER, Ctr Brest, GM, F-29280 Plouzane, France.

${ }^{4}$ IFP Energies Nouvelles, F-92852 Rueil Malmaison, France.

* Corresponding author : Estelle Leroux, email address : Tel.: (+33)6 82607163 ;

email address : stll.leroux@gmail.com

\begin{abstract}
:
Deep Earth dynamics impact so strongly on surface geological processes that we can use sediment palaeo-markers as a window into the deeper Earth. Derived from climatic and tectonic erosive actions on the continents, and related to eustasy, subsidence and isostasy, the sediment in a deep basin is the main recorder of these processes. Nevertheless, defining and quantifying the relative roles of parameters that interact to give the final sedimentary architecture is not a simple task. Using a 3D-grid of seismic and wide-angle data, boreholes and numerical stratigraphic modelling, we propose here a quantification of post-rift vertical movements in the Provençal Basin (West Mediterranean) involving three domains of subsidence: seaward tilting on the platform and the slope and purely vertical subsidence in the deep basin. These domains fit the deeper crustal domains highlighted by previous geophysical data. Post-break-up sedimentary markers may therefore be used to identify the initial hinge lines of the rifting phase and the subsidence laws.
\end{abstract}


INTRODUCTION

31 Whilst the link between deep Earth dynamics and surface geologic processes appears more and more as a key parameter, deep Earth research, encompassing fields such as seismology and mantle geodynamics, has traditionally operated distinctly from fields focusing on surface dynamics, such as sedimentology and geomorphology [Cloetingh et al., 2013]. Nevertheless, the formation of passive continental margins -namely the process by which the continental lithosphere thins and subsides that remains one of the main challenges in Earth Science-,

37 allows recording in its sedimentary layers the main steps of the Earth dynamic processes (subsidence, uplift, erosion, paleoclimate...). Passive margins represent a sink for sediments resulting from climate and tectonic erosive actions on the continents. Sedimentary layers also record the effects of eustasy, subsidence and isostasy, so that sediment appears as a storyteller 41 of the Earth.

42 We present here a quantification of the post-rift vertical movements of the Provence Basin 43 (West Mediterranean) based on the interpretation of sedimentary paleomarkers using a large 3D grid of seismic data, correlations with existing drillings, refraction data and validation by numerical stratigraphic modelling with Dionisos [Granjeon \& Joseph, 1999]. The results of this 3D analysis emphasize the strong link between deep Earth dynamic processes and surface 47 geologic processes.

\section{Geological Setting}

The Provence Basin reveals a structure and evolution corresponding to a young pair of rifted margins formed by the counter-clockwise rotation of the Corso-Sardinian micro-blocks with 
52 respect to the Ibero-European plate from the Late Eocene (Priabonian, 33.7 Ma), in a general 53 context of collision between Africa and Europe (Figure 1-A). The opening took place at the 54 southern end of the intra-European rift system, in a back-arc situation, in response to SE rollback of the slab of the African plate subducting beneath the European plate during an extensional phase. This Corso-Sardinian micro-continent rotation resulted in the emplacement of oceanic crust, starting in the Late Aquitanian (23 Ma to $19 \mathrm{Ma}$ ) and ending in the Langhian (about $15 \mathrm{Ma}$ ) [Olivet, 1996].

Thanks to its recent history, the subsidence in the Provence Basin is still underway at present and continually creates a large amount of space which favours a progressive filling that 61 preserves the record of both the comings and goings of shorelines associated with the rise and fall of sea levels as well as the vertical movements of the margin [Rabineau et al., 2005]. This fact, together with the substantial seismic database available on the Provence margin, including conventional standard seismic lines, high-resolution multi-channel data, very highresolution profiles and industrial drillings make this basin ideal for constraining evolutionary and subsidence models of rifted continental margins using the sedimentary record.

DATA AND METHODS

Many global, regional and local factors have long been recognised to control the overall geometry and deposition of sediments but defining and quantifying the relative part of parameters interacting to produce the final sedimentary architecture of basins (subsidence, eustasy, sediment supply) is not a simple task. This has been one of the main goals of Seismic and Sequence Stratigraphy, as developed in the late 70's [Mitchum and Vail, 1977;

74 Posamentier, 1988a]. At the same time, the development of quantitative techniques for geological analysis of sedimentary basins (geohistory analysis) were developed [Van Hinte, 
77 for subsidence and sediment accumulation rates through time. This is reached after a number 78 of corrections (decompaction, paleobathymetry and absolute sea-level fluctuations) based on 79 available datasets. The total subsidence is therefore partitioned into contributions from 80 tectonic driving forces, thermal evolution, sediment loading and sea-level fluctuations 81 [Steckler and Watts, 1978; Allen \& Allen, 2005]. This backstripping depends on strong 82 assumptions: the isostatic response of the lithosphere (e.g. Airy vs regional flexure), 83 theoretical law for porosity, paleobathymetries, sea-level changes, densities of mantle and 84 crust and thermal subsidence. Moreover, lateral and longitudinal variations along a margin are 85 important and 1D modeling cannot be applied to the entire margin.

86 Rabineau et al. [2014] presented a new method to quantify the post-rift subsidence by the 87 direct use of sedimentary geometries. In this paper, we apply this method in a 3D analysis of 88 sedimentary geometries. In a first step, seismic stratigraphy and borehole data have been used 89 to interpret and date the paleosurfaces on all profiles. Those have been correlated at a regional 90 scale and converted in depth using ESP and sonic data from wells to generate isobath and 91 isopach maps and to quantify sediment fluxes through time [Leroux, 2012]. In a second step, 9210 fictitious regional lines were extracted from this set of isobath maps (Figure 1-B). We then 93 built vertical dip and strike sections in order to quantify the $3 \mathrm{D}$ vertical evolution and 94 potential tectonic deformation of the margin. On each profile, we adjusted paleosurfaces to 95 straight lines, to mesure their subsidence rates (Figure 1-C). This method highlights not only 96 the evolution of subsidence through time but also its spatial segmentation along the margin. 97 98 QUANTIFICATION OF SUBSIDENCE 
99 For each profile, three domains of different subsidence were identified by dips and slope-

100 breaks of each horizon ${ }^{1}$ (Figure 1-C). Subsidence on the shelf is characterised by a Plio-

101 Quaternary tilt of $0.16^{\circ} / \mathrm{Myr}$ about a rotational axis located $15 \mathrm{~km}$ landward of the present-

102 day coastline (Hinge Line 1, HL1). This Plio-Quaternary subsidence is constant through time

103 [Leroux et al., 2014]. During the Miocene, this rate varies spatially: 0,12\% $\mathrm{Myr}$ on the western

104 sections and $0.06^{\circ} / \mathrm{Myr}$ on the eastern sections, using the same hinge line 1.

105 Seawards of the hinge line 3 (HL3), in the distal part of the margin, Miocene and Plio-

106 Quaternary reflectors are flat and parallel to the substratum, indicating a purely vertical

107 subsidence. The strong early erosion at the top of the synrift deposits or directly on the

108 substratum suggests a subaerial position of the substratum before the first post-rift deposit

109 [Bache et al., 2010]. This erosional surface is observed on the entire margin and allows us to

110 consider a high position of the entire margin (with a paleobathymetry above sea-level) at the

111 end of rifting. Considering an age of $20 \mathrm{Ma}$ for the end of rifting [Séranne, 1999], we can then

112 calculate the mean post-rift vertical subsidence rate in the deep basin of $500 \mathrm{~m} / \mathrm{Myr}$.

113 Between these two domains, the slope accommodates vertical movements of either side.

114 Whilst the slope break between the slope and the deep basin (hinge line 3) is fixed in space

115 through time, the hinge line 2 (HL2) between the shelf and the slope varies during the

116 Pliocene within an area of less than $20 \mathrm{~km}$, which mainly reflects the prograding-aggrading

\footnotetext{
${ }^{1}$ Plio-Quaternary key reflectors labelled MES (Margin Erosional Surface in pink), P11 (yellow), PXX (turquoise-blue), Q10 (red), Q5 (purple) and seafloor (marine-blue) are respectively dated at $5.33 \mathrm{Ma}$, 2.6 Ma, 1.6 Ma, 0.9 Ma, 0.5 Ma and 0 Ma [Leroux et al., 2014]. The substratum (brown) and Miocene markers such as the base of the MSC (Messinian Salinity Crisis in red), the base of Mb -interpretated as an evaporitic unit- (orange), the base and top of salt (green and light green) and the top of UU (Upper Unit in grey) are from [Bache et al., 2009].
} 
117 sedimentary system on the shelf [Rabineau et al., 2014] rebuilding the margin after the

118 Messinian erosional event [Lofi et al., 2003].

119 This 3D quantification of subsidence in three domains was then tested with Dionisos

120 [Granjeon and Joseph, 1999] using the quantitative constraints on sediment supply inferred

121 from a 3D stratigraphic analysis (Leroux, 2012, Leroux et al., 2014, Fig S1. in Supplementary

122 Material) and the eustatic curve of Haq et al., (1987), modified by a $1500 \mathrm{~m}$ drawdown during

123 the MSC [Clauzon et al., 1982] (Fig S1. in Suppl. Material).

124 Figure 2 demonstrates that the 3D modelling successfully restores the stratigraphic record

125 with the sedimentary geometries and thicknesses observed from seismic data. This modelling

126 is coherent with micropaleontological data from Miocene borehole samples on the shelf

127 [Cravatte et al., 1974] that reveals a deepening of the depositional environment at this time

128 (see Figures S1, S2, S3 and movies S4, S5, S6 in Suppl. Material). The aggrading shelf-slope

129 geometries during the Early to Middle Miocene indicate that the morphology of the margin

130 and the subsidence pattern changed after this early erosion and led to the creation of

131 accommodation. After rifting, the entire Gulf of Lions margin was thus affected by strong

132 post-rift subsidence leading to thick post-rift (Miocene to Quaternary) sedimentary

133 accumulations. After the MSC we can observe a Pliocene progradation trend followed by a

134 Pleistocene progradation-aggradation trend (after 2.6 Ma). All these elements are well

135 reproduced by our simulation.

136 Western Mediterranean basins and margins have undergone a transition into Late Neogene

137 basin inversion (e.g. Roure et al., 2013). Increase in the level of intraplate compression in the

138 Northern Atlantic region could explain the observed rapid phases of Plio-Quaternary 139 subsidence after a phase of quiescence [Cloetingh \& Kooi, 1992]. Moreover, in the Gulf of

140 Lion, sediment flux during Pliocene (after 5.33 Ma) is 3 times higher than the flux in the

141 Miocene (Figure S1 in Suppl. Material). This increasing sediment load, driven by climate or 
142 tectonic, may therefore play an important role in the increasing subsidence. However, since

143 2004, many studies on passive margins, which are not in back-arc setting nor in inversion,

144 have shown delayed subsidence which increases long after the breakup, as on Spitzberg

145 Margin [Ritzmann, et al., 2004], on Iberia-Newfoundland Margins [Peron-Pinvidic \&

146 Manatschal, 2008], on Morocco Margin [Labails et al., 2009], on Brazilian margins [Aslanian

147 et al., 2009), on Angola margin [Moulin et al., 2005] or on the Gulf of Lion margin [Bache et

148 al., 2010; Aslanian et al., 2012; Moulin et al., in press]. In some margins, the presence of

149 carbonates overlying the salt layer shows that a shallow environment lasted after the break-up.

150 The subsidence rate then seems to increase rapidly. The general character of the delayed

151 subsidence followed by an increased subsidence rate implies probably a deep contribution like

152 a lithosphere driven process (as proposed by Aslanian et al., 2009; Huismans \& Beaumont,

153 2011, 2014; Aslanian et al., 2012), whithout excluding basin inversion process and/or

154 sediment overloading".

\section{CORRELATION WITH THE UNDERLYING CRUSTAL DOMAINS}

157 Four structural domains extending from the coast to the oceanic crust have been highlighted 158 on the basis of gravity, magnetic, reflection and wide-angle seismic data (Figure 3) [Pascal et

159 al., 1993, Gailler et al., 2009, Aslanian et al., 2012, Moulin et al., in press; Afilhado et al., in

160 press]: a) a $20 \mathrm{~km}$ thick continental crust (thinned crust), b) a highly thinned continental zone

161 (the continental necking zone as described by Kooi et al., 1992; Cloetingh et al., 1995),

162 which is marked by a prominent reflector (T) easily recognised at depth [De Voogd et al.,

1631991 ; Moulin et al., in press], c) a $5 \mathrm{~km}$ thin domain of unknown crust and complex nature

164 (called a transitional domain), and last d) a thin oceanic crust. The limit between the necking

165 and the transitional domains corresponds to the French-side limit of the pre-rift

166 paleogeography [Olivet, 1996]. The base of the necking and transitional domains presents a 4 
$167 \mathrm{~km}$ thick layer with anomalous seismic velocities $(6.8-7.5 \mathrm{~km} / \mathrm{s})$ which are neither typical of 168 continental crust nor oceanic crust [Pascal et al., 1993, Gailler et al., 2009; Moulin et al, in 169 press, Afilhado et al., in press.]. The nature of the transitional domain was a matter of debate 170 [De Voogd et al., 1991; Pascal et al., 1993 ; Séranne, 1999 ; Gailler et al., 2009 ; Bache et al., 1712010 ; Aslanian et al., 2012] but the recent results of wide-angle seismic analysis seem in 172 favour of an exhumed lower continental crust nature [Moulin et al., in press; Afilhado et al., 173 in press]. This is beyond the scope of this paper, but a consensus does exist on the very 174 different nature of this crust compared to the crustal domains observed on both sides, and the 175 transitional crust may have different physical behaviour.

176 Figure 3 presents our reconstructed 3D subsidence map and the striking correlation between

177 the three differential subsidence domains described using paleo-markers and the underlying 178 crustal domains highlighted by geophysical data. Up to present day, the crustal limits defined 179 by the passive margin genesis still control, at the very first order, the vertical movements 180 recorded by sedimentary sequences.

182 Not all passive margins exhibit a sag basin, with a «pure » vertical subsidence. Therefore, the 183 use of depositional architecture can give a first approximation for the partitioning of the 184 subsidence (with or without a sag basin) and the basement surface geometry.

185 In the GOL, the sag basin is described to be allochthonous, with exhumed lower crust near the 186 necking and anomalous thinned oceanic crust in the middle of the basin [Aslanian et al., 187 2012; Moulin et al., in press; Afilhado et al., in press]. This partitioning, with different 188 magnetic and gravity patterns, fits the palaeogeographic reconstructions and is also observed 189 in the salt geometry (connected/separated domes).

190

191 Using wide-angle and reflection seismic data, a similar observation was made for the Angola 192 Margin, where the sag basin exhibits a similar mainly vertical, pre-breakup and post-breakup 
193 subsidence [Moulin et al., 2005; Aslanian et al., 2009]. As shown in the Gulf of Lion, the

194 post-break-up subsidence of the Angolan basin uses the same hinge lines that have built and 195 segmented the passive margin [Moulin et al., 2005]. However, the nature of its basement is 196 different from the GOL, with an autochthonous upper continental crust (just after the necking) 197 and an allochthonous crust that can be exhumed or intruded [Moulin et al., 2005; Aslanian et 198 al., 2009]. This partitioning is also observed in the salt geometry (connected/separated 199 domes), and fits the initial palaeogeographic reconstruction [Moulin et al., 2010; Aslanian \& 200 Moulin, 2010; 2012].

201 The difference between the two examples shows that a sag basin can occur with different 202 crustal nature as shown by geophysical data. In both cases the exhumed/intruded lower 203 continental crust is involved. The wide angle results in GOL [Afilhado et al., in press] and in 204 the Santos Basin [Klingelhoefer et al., 2015; Evain et al., accepted] show that the transition 205 between exhumed lower crust to oceanic crust is not abrupt and raises the question on the role 206 of the lower continental crust "flow", that can be gradually recrystallized to build the first 207 atypical oceanic crust [Bott, 1971; Aslanian et al., 2009: Sibuet et al., 2012; Evain et al., 208 accepted; Afilhado et al., in press].

209 Anyway, in both cases, whilst the combination of depositional architecture, surface

210 observations and palaeogeographic reconstructions will not give the exact crustal nature, they 211 can give crucial information such as: basement surface geometry, 212 allochthonous/autochthonous nature, and, thanks to magnetism, oceanic nature.

\section{CONCLUSION}

215 Using the new method of Rabineau et al. [2014] to quantify the post-rift subsidence by the 216 direct use of sedimentary geometries on the 3D analysis of tilts of stratigraphic markers in the 217 Gulf of Lions margin, we individualize three domains of subsidence: on the platform and 
218 slope, the subsidence takes the form of a seaward tilting with different amplitudes, whereas

219 the deep basin subsides purely vertically, as in the case of a sag basin. These domains fit with

220 the deeper crustal domains highlighted by previous geophysical data implying that the post-

221 break-up subsidence re-uses the initial hinge lines of the rifting phase and that the

222 sedimentary record (even the last $5 \mathrm{Ma}$ ) is correlated with the underlying structural domains.

223 This study provides therefore strong evidence for the recognition and importance of the link

224 between deep Earth dynamic processes and surface geological processes [e.g. Braun, 2010,

225 Cloetingh et al., 2013]. The vertical coupling between mantle and surface processes promises

226 new insights into past mantle dynamics through the geological record and the sediments are a

227 precious tool for deciphering the laws of subsidence, even in their recent history, and can be

228 considered as the storyteller of vertical and horizontal movements (Rabineau, 2014) and can

229 be used as a window on deep geodynamic processes.

231 ACKNOWLEDGEMENTS

232 Stratigraphic simulations were performed with IFP-Energies Nouvelles Dionisos software

233 kindly made available to the University of Brest. This research was mainly funded by CNRS

234 and IFREMER, with additional support from the French Actions-Marges program (JL Rubino

235 \& P. Unternehr) and the GRI "Méditerranée" (Groupement Recherche et Industrie). This

236 work also benefited from the Labex Mer initiative, a State Grant from the French Agence

237 Nationale de la Recherche (ANR) in the Program "Investissements d'avenir » with the

238 reference ANR-10-LABX-19-01, Labex Mer. The authors are grateful to Katalin Kovacs for

239 post-editing the English style. We also thanks Jim Pindell and an anonymous reviewer for

240 their very fruitful comments that greatly improved this paper, as well as Max Coleman,

241 Scientific Editor and the anonymous associated editor for their reading and encouragements. 


\section{Competing financial interests}

244 The authors declare no competing financial interests.

\section{FIGURE CAPTIONS}

247 Fig1. (A) Location of the study area (black box) on a bathymetric map of the Provence Basin.

248 Opening of the basin is illustrated by black arrows. Shaded area corresponds to the oceanic

249 crust domain. (B) Location of all our synthetic vertical sections on our bathymetric map

250 drawn from seismic data (B). This map also shows the extension of our stratigraphic

251 interpretation and the position (red line) of the dip section shown on (C) in which the tilts and

252 the subsidence of stratigraphic paleosurfaces are analysed. Colored circles correspond to

253 slope-breaks for each of these surfaces. Three hinge-lines (grey area) are noted. On the shelf

254 these stratigraphic surfaces allowed us to measure a constant Plio-Quaternary subsidence tilt 255 rate $\left(0.16^{\circ} / \mathrm{Myr}\right)$. The tilt rate of the substratum is $0.11^{\circ} / \mathrm{Myr}$ if we denote the end of rifting at

$25620 \mathrm{Ma}$. In the basin, the post-rift subsidence is purely vertical; its mean rate is estimated at 257 around $500 \mathrm{~m} / \mathrm{Myr}$ (see the text for explanation).

259 Figure 2. (A) Deposit paleobathymetries and resultant geometries predicted by Dionisos in 260 our 3D stratigraphic modelling of the Gulf of Lion and Provence basin. The sedimentary 261 architecture of the margin and final depths of the stratigraphic markers (relative to the 262 substratum) are well reproduced by the model. We can compare this simulation with the NW263 SE seismic profile ECORS 1 on (B): on both we observe the deepening of the Miocene 264 depositional environment, the Messinian trilogy (LU, MU \& UU after Lofi et al., 2011) and 265 the prograding trend during the Pliocene followed by a prograding-aggrading trend during the 266 Pleistocene (after 2.6 Ma). Note that the vertical scale units are respectively metres in A and 267 seconds (twtt) in B. This explains the relative differences in unit thicknesses, in particular for 
268 the pre-Messinian Miocene unit. See also seismic lines corresponding to the black boxes S1 \&

269 S2 in the supplementary information.

270

271 Figure 3. (A) 3D post-rift subsidence map drawn after our seismic interpretation and the

272 analyses of our 10 synthetic vertical sections. The structural domains highlighted by

273 geophysical data [Moulin et al., in press] and the geometries of the post-rift sedimentary pile

274 are reported along a NW-SE dip line-drawing (B). There exists a striking correlation between

275 the sedimentary record of subsidence and the nature of the underlying crust. The continental

276 crust (domains 1 and 2) is tilted whereas the intermediate COT (Continent-Ocean Transition)

277 domain (domain 3) subsides in a purely vertical way, such as in a sag basin. See the text for

278 explanation.

279

280 SUPPLEMENTARY MATERIAL

281 - Figure S1. Major input parameters (evolution of the eustatic curve and sediment supply) for

282 the 3D simulation of post-rift filling of the Provence basin. The simulation was run over the

283 last $20 \mathrm{Ma}$ with a $0.1 \mathrm{Ma}$ time-step. The basin is defined as a rectangular area $(250 \times 400 \mathrm{~km})$

284 and the initial basement at $20 \mathrm{Ma}$ is flat with a paleobathymetry around $+100 \mathrm{~m}$ (cf text for

285 explanation).

286

287 - Figure S2. Interpretated LRM18 seismic reflection profile. The offlap-breaks are represented

288 with white dots; Inset: the overall geometry of Pliocene-Quaternary strata shows prograding

289 clinoforms (or prisms) with a clear geometrical change in the Late Pliocene to Quaternary

290 clinoforms (after yellow horizon p11), from essentially prograding (green) to prograding-

291 aggrading (yellow). Leroux et al., 2014 (in press).

292 
293

294

295

296

297

298

299

300

301

302

303

304

305

306

307

308

309

310

\section{REFERENCES CITED}

312

313 Afilhado, A., Moulin, M., Klingelhoefer, F., Aslanian, D., Schnurle, P., Nouzé, H., Rabineau, M. \& Beslier,

314 M.O., in press. Deep crustal structure across an young passive margin from wide-angle and reflection seismic

315 data (The SARDINIA Experiment) - II. Sardinia's margin, BSGF, ILP Special volume, in press.

316 Allen, P. and Allen, J., 1990. Basin analysis, Principles and Applications (Blackwell Publishing Ltd, 1st Edition, 317 1990), $451 \mathrm{pp}$.

318 Allen, P. and Allen, J., 2005. Basin analysis, Principles and Applications (Blackwell Publishing Ltd, Second 319

- Figure S3. Comparison between (A) a regional seismic profile from (Bache, 2009) and (B)

- Movie S4. 3D stratigraphic model of the Gulf of Lions and Provence basin from 20 to 0 Ma. The movie shows deposit paleobathymetries and resultant geometries predicted by Dionisos.

- Movie S5. Evolutional model of the Gulf of Lions and Provence basin through 3D stratigraphic modelling during the Messinian Salinity Crisis. The movie shows deposit paleobathymetries and resultant geometries predicted by Dionisos.

- Movie S6. Evolutional model of the Gulf of Lions and Provence basin through 3D stratigraphic modelling during the Messinian Salinity Crisis. The movie shows lithologic facies and resultant geometries predicted by Dionisos. Edition), 549 pp. 
Aslanian, D., Moulin, M., Olivet, J.-L., Unternehr, P., Matias, L., Bache, F., Rabineau, M., Nouzé, H.,

321 Klingelhoefer, F., 2009. Brazilian and african passive margins of the central segment of the south atlantic ocean:

322 Kinematic constraints, Tectonophysics, 468, 98-112.

323 Aslanian, D. \& Moulin, M., 2010. Comments on «A new scheme for the opening of the south Atlantic Ocean

324 and the dissection of an Aptian salt Basin» from Torsvik et al, 2009. Geophys. J. Int. 183, 20-28.

325 doi:10.1111/j.1365-246X.2010.04727.x.

326 Aslanian, D. \& Moulin, M., 2012. Paleogeographic consequences of conservational models in the South Atlantic

327 Ocean. In: W.U. Mohriak, A. Danforth, P.J. Post, D.E. Brown, G.C. Tari, M. Nemcok, S.T. Sinha (Eds.),

328 Conjugate Divergent Margins, Geological Society, London, Special Publications, 369.

329 Aslanian, D., Rabineau, M., Moulin, M., Schnurle, P., Klingelhoefer, F., Gailler, A., Bache, F., Leroux, E.,

330 Gorini, C., Droxler, A., Eguchi, N., Kuroda, J., Alain, K., Roure, F. \& Haq, 2012. Structure and evolution of the

331 Gulf of Lions: the Sardinia seismic experiment and the GOLD (Gulf of Lions Drilling) project. Leading Edge.

332 Bache, F., Olivet, J.-L., Gorini, C., Rabineau, M., Baztan, J., Aslanian, D., Suc, J.-P., 2009. Messinian erosional

333 and salinity crisis: View from the Provence basin (Gulf of Lions, Western Mediterranean). Earth and Planet. Sci.

334 Lett., 286, 139-157.

335 Bache, F., Olivet, J.-L., Gorini, C., Aslanian, D., Labails, C. and Rabineau, M., 2010. Evolution of rifted

336 continental margins : The case of the gulf of lions (western mediterranean basin), Earth and Planet. Sci. Lett.,

$337292,345-356$.

338 Bott, M.P.H., 1971. Evolution of young continental margins and formation of shelf basins. Tectonophysics, 11 339 (5), 319-327.

340 Braun, J., 2010. The many surface expressions of mantle dynmics. Nature Geosci. 3, 825-833.

341 Clauzon, G., 1982. Le canyon messinien du rhône : une preuve décisive du dessicated deep-basin model. Bull.

342 Soc. Geol. France 24, 597-610.

343 Cloetingh, S. \& Kooi, H., 1992. Tectonics and global change -inferences from Late Cenozoic subsidence and

344 uplift patterns in the Atlantic/Mediterranean region. Terra Nova (Global Change Spec. Issue), 4, 340-350.

345 Cloetingh, S., van Wees, J.D., van der Beek, P.A., Spadini, G., 1995. Role of pre-rift rheology in kinematics of

346 extensional basin formation: constraints from thermomechanical models of Mediterranean and intracratonic 347 basins. Mar. Petrol. Geol, 12 (8), 793-807.

348 Cloetingh, S. \& Willett, S.D., 2013. TOPO-EUROPE: Understanding of the coupling between the deep Earth 349 and continental topography. Tectonophysics, 602, 1-14. 
350 Contrucci, I., Matias, L., Moulin, M., Géli, L., Klingelhoefer, F., Nouzé, H., Aslanian, D., Olivet, J.-L., Sibuet, 351 J.-C., Réhault, J.-P., 2004. Deep structure of the west african continental margin, between $5^{\circ} \mathrm{s}$ and $8^{\circ} \mathrm{s}$, from 352 reflection/refraction seismics and gravity data, Geophys. J. Int., 158, 529-553.

353 Cravatte, J., Dufaure, P., Prim, M., Rouaix, S., 1974. Les sondages du golfe du lion : Stratigraphie, 354 sédimentologie, Compagnie Française des Pétroles, Paris.

355 De Voogd, B., Nicolich, R., Olivet, J.L., Fanucci, F., Burrus, J., Mauffret, A., Pascal, G., Argnani, A., Auzende, 356 J.M., Bernabini, M., Bois, C., Carmignani, L., Fabbri, A., Finetti, I., Galdeano, A., Gorini, C.Y., Labaume, P., 357 Lajat, D., Patriat, P., Pinet, B., Ravat, J., Ricci Lucchi, F., Vernassa, S., 1991. First deep seismic reflection 358 transect from the Gulf of Lions to Sardinia (ECORS-CROP profiles in Western Mediterranean). In: Meissner, R. 359 (Ed.), Continental Lithosphere: Deep seismic reflections. American Geophysical Union, 265-274.

360 Evain, M., Afilhado, A., Rigoti, C., Loureiro, A., Alves, D., Klingelhoefer, F., Schnurle, P., Feld, A., Fuck, R., 361 Soares, J., Vinicius de Lima, M., Corela, C., Matias, L., Benabdellouahed, M., Baltzer, A., Rabineau, M., Viana, 362 A., Moulin, M., Aslanian, D. (accepted). Deep structure of the Santos Basin-Sao Paulo Plateau System, SE 363 Brazil. J. Geophys. Research, xx, xx-xx.

364 Gailler, A., Klingelhoefer, F., Olivet, J.-L., Aslanian, D., the Sardinia scientific party, and T. O. team, 2009.

365 Crustal structure of a young margin pair: new results accross the liguro-provencal basin from wide-angle seismic 366 tomography. Earth and Planet. Sci. Lett., 286, 333-345.

367 Granjeon, D., Joseph, P., 1999. Concepts and applications of a 3-d multiple lithology, diffusive model in 368 stratigraphic modelling. In: Numerical Experiments in Stratigraphy:Recent Advances in Stratigraphic and 369 Sedimentologic Computer Simulation, SEPM Spec. Pub. 62, Tulsa, 197-210.

370 Haq, B.U., Hardenbol, J., Vail, P., 1987. Chronology of fluctuating sea levels since the Triassic (250 million 371 years ago to present). Sci., 235, 1156-1167.

372 Huismans, R. \& Beaumont, C., 2011. Depth-dependant extension, two-stage breakup and cratonic underplating 373 at rifted margins. Nature, 473, 74-79.

374 Huismans, R. \& Beaumont, C., 2014. Rifted continental margins: the case for depth-dependent extension. Earth 375 and Planet. Sci. Lett., 407, 148-162.

376 Jervey, M.T., 1988. Quantitative geological modelling of siliclastic rock sequences and their seismic 377 expressions, in: Wilgus, C.K., Hastings, B.S., St Kendall, C.G., Ross, C.A., Van Wagoner, J.C. (Eds.), Sea-level 378 changes: an integrated approach. SEPM Special Publication, Tulsa, pp. 47-69. 
379 Klingelhoefer, F., Evain, M., Afilhado, A., Rigoti, C., Loureiro., A., Alves, D., Leprêtre, A., Moulin, M.,

380 Schnurle, P., Benabdellouahed, M., Baltzer, A., Rabineau, M., Feld, A., Viana, A., Aslanian, D., 2015. Imaging

381 proto-oceanic crust off the Brazilian Continental Margin. Geophys. J. Int., 200 (1), 471-488.

382 Kooi, H., Cloetingh, S., Burrus, J., 1992. Lithospheric Necking and Regional Isostasy at Extensional Basins. 1.

383 Subsidence and Gravity Modeling with an Application to the Gulf of Lions margin (SE France). J. of Geophys.

384 Research, 97(B12), 17553-17571.

385 Labails, C. \& Olivet J.-L. \& the Dakhla study group, 2009. Crustal structure of the SW Moroccan margin from

386 wide-angle and reflection data (the Dakhla experiment). Part B., The tectonic heritage. Tectonophysics, 468 (1-

387 4), 83-97.

388 Leroux, E., 2012 Quantification des flux et de la subsidence du bassin Provençal (Méditerranée occidentale).

389 PhD, Université de Bretagne Occidentale, 457 pp. http://archimer.ifremer.fr/doc/00108/21967/20279.pdf

390 Leroux, E., Rabineau, M., Aslanian, D., Gorini, C., Droz, L., Granjeon, D., 2014. Stratigraphic simulation on the

391 shelf of the Gulf of Lions : testing subsidence rates and sea-level curves during Pliocene and Quaternary, Terra

392 Nova, doi: 10.1111/ter.12091.

393 Lofi, J., Rabineau, M., Gorini, C., Berné, S., Clauzon, G., Clarens, P. D., Reis, A. D., Mountain, G. S., Ryan,

394 W., Steckler, M., Fouchet, C., 2003. Plio-quaternary prograding clinoform wedges of the Western Gulf of Lion

395 continental margin (NW Mediterranean) after the messinian salinity crisis, Mar. Geol., 198, $289-317$.

396 Lofi, J., Sage, F., Deverchère, J., Loncke, L., Maillard, A., Gaullier, V., Thinon, I., Gillet, H., Guennoc, P.,

397 Gorini, C., 2011. Refining our knowledge of the Messinian Salinity crisis records in the offshore domaine

398 through multi-site seismic analysis. Bull. Soc. Géol. Fr., 182, 163-180.

399 Moulin, M., Aslanian, D., Olivet, J.-L., Contrucci, I., Matias, L., Géli, L., Klingelhoefer, F., Nouzé, H., Rehault,

400 J.P., Untemehr, P., 2005. Geological constraints on the evolution of the angolan margin based on reflection and

401 refraction seismic data (ZaïAngo project). Geophys. J. Int., 162, 793-818.

402 Moulin, M., Aslanian, D., Unternehr, P., 2010. A new starting point for the South and Equatorial Atlantic Ocean,

403 Earth-Science Reviews, 98(1-2), 1-37.

404 Moulin, M., Klingelhoefer, F., Afilhado, A., Feld, A., Aslanian, D., Schnurle, P., Nouzé, H., Rabineau, M.,

405 Beslier M.O., in press. Deep crustal structure across a young passive margin from wide-angle and reflection

406 seismic data (the sardinia experiment) - I. Gulf of Lions margin.. BSGF, ILP Special volume.

407 Mitchum, R.M., Vail, P.R., Thompson, S., 1977a. Seismic stratigraphy and global changes of sea level, part 2:

408 the depositional sequence as a basic unit for stratigraphic analysis, in: Payton, C.E. (Ed.), Seismic stratigraphy - 
409

410

411

412

413

414

415

416

417

418

419

420

421

422

423

424

425

426

427

428

429

430

431

432

433

434

435

436

437

Application to hydrocarbon exploration. AAPG Mem. 26, Tulsa, Oklahoma, pp. 53-62.

Olivet, J.-L., 1996. La cinématique de la plaque ibérique, Bulletin du Centre de Recherche et d'Exploration, Production Elf Aquitaine, 20, 131-195.

Pascal G., Mauffret, A., Patriat, P., 1993. The ocean-continent boundary in the Gulf of Lions from analysis of expanding spread profiles and gravity modelling. Geophys. J. Int. 113, 701-726

Peron-Pinvidic, G. \& Manatschal, G., 2008. The final rifting evolution at deep magma-poor passive margins from Iberia-Newfoundland: a new point of view. Int. J. Earth Sci. (Geol Rundsch), 98, 1581-1597. DOI 10.1007/s00531-008-0337-9.

Posamentier, H.W., Jervey, M.T., Vail, P.R., 1988a. Eustatic controls on clastic deposition I. Conceptual framework, in: Wilgus, C.K., Hastings, B.S., Kendall, C.G.S.C., Posamentier, H.W., Ross, C.A., Van Wagoner, J.C. (Eds.), Sea-Level Changes- an Integrated Approach. SEPM Spec. Pub. 42, Tulsa, pp. 102-124.

Rabineau, M., Berné, S., Aslanian, D., Olivet, J.-L., Joseph, P., Guillocheau, F., Bourillet, J.-F., Le Drezen, E., Granjeon, D., 2005. Sedimentary sequences in the gulf of lions : A record of 100,000 years climatic cycles, Marine and Petroleum geology, 22, 775-804.

Rabineau, M., Leroux, E., Bache, F., Aslanian, D., Gorini, C., Moulin, M., Molliex, S., Droz, L., Reis, A.D., Ritzmann,O., Jokat., W., Czuba, W., Guterch, A., Mjelde, R., Nishimura, Y., 2004. A deep seismic transect from Hovgard Ridge to northwestern Svalbard across the continental-ocean transition: A sheared margin study. Geophys. J. Int., 157(2), 638-702.

Rubino, J.-L., Olivet, J.-L., 2014. Quantification of pliocene-quaternary subsidence and isostatic readjustment related to the messinian crisis (using paleobathymetric markers in the Gulf of Lion). Earth Planet. Sci. Lett. 388, $1-14$.

Robin, C., Guillocheau, F., Gaulier, J.M., 1996. Mesure des signaux eustatiques et tectoniques au sein de l'enregistrement sédimentaire d'un bassin intracratonique. Application au Lias du bassin de Paris. Comptes Rendus de l'Académie des Sciences de Paris 322, 1079-1086.

Roure, F.M., Casero, P., Addoum, B., 2013. Mesozoic and Cenozoic Basins Formation and Deformation along the North African Margin. Search and Discovering Article \#30276, AAPG2013.

Séranne, M., 1999. The Gulf of Lion continental margin (NW MEditerranean) revisited by IBS: an overview, in: Steckler, M.S. \& Watts, A.B., 1978. Subsidence of the Atlantic-type continental margin off New York. Earth and Planetary Science Letters, 41 (1), 1-13. 
438 Sibuet, J.-C. \& Tucholke, B.E., 2012. The geodynamic province of transitional lithosphere adjacent to magma439 poor continental margins. Geol. Society, London, Special Publication, 369, 429-452.

440 Durand, B., Jolivet, L., Horvath, F., Seranne, M. (Eds.), The Mediterranean Basins: Tertiary Extension within

441 the Alpine Orgogen. Special publication, Geological Society of London.

442 Van Hinte, J.E., 1978. Geohistory analysis: application of micropaleontology in exploration geology. Bull. Am.

443 Ass. Pet. Geol. 62, 201-222.

444

445

446 


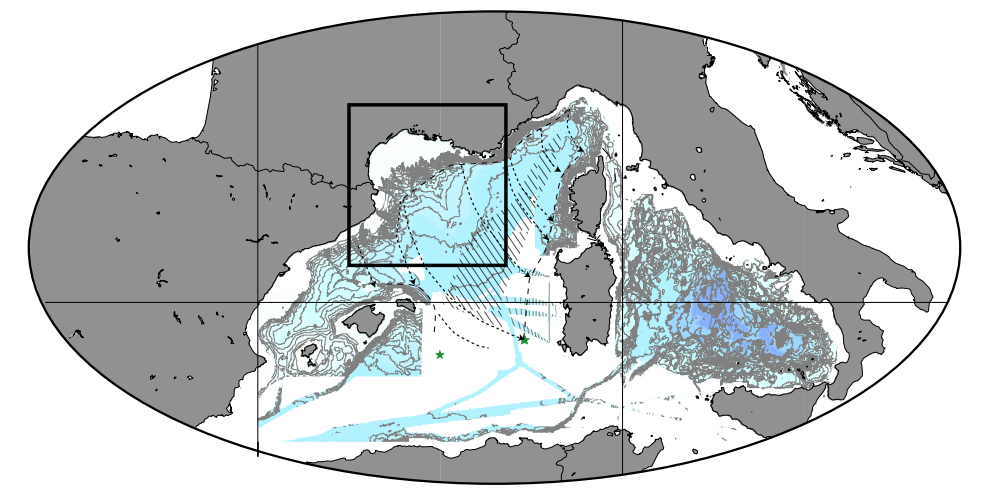

For Review Only

\begin{tabular}{|llll|}
\hline ○ Seafloor & O & Top of Salt \\
○ Q5 & ○ & Base of Salt \\
O Q10 & O & Base of Mb \\
O PXX & O & Base of M unit \\
O P11 & O & \\
○ Top of UU & ○ & Substratum \\
\hline
\end{tabular}

C)

Hinge Line 1:

Hinge Line 2:

Starting point of the tilt

(Paleo) Shelf breaks



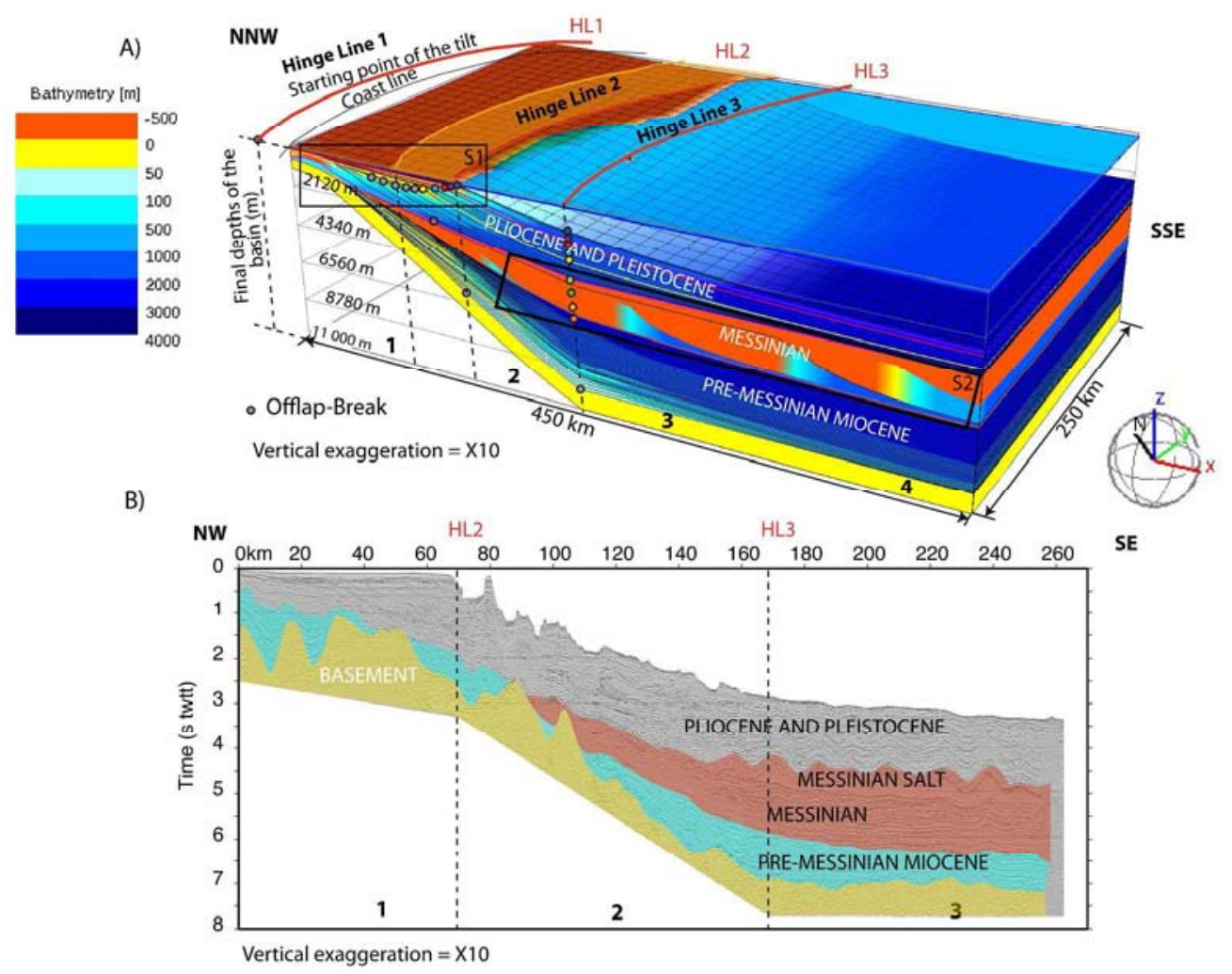

Deposit paleobathymetries and resultant geometries predicted by Dionisos in our 3D stratigraphic modelling of the Gulf of Lion and Provence basin (A). The sedimentary architecture of the margin and final depths of the stratigraphic markers (relative to the substratum) are well reproduced by the model. We can compare this simulation with the NW-SE seismic profile ECORS 1 on (B): on both we observe the deepening of the Miocene depositional environment, the Messinian trilogy and the prograding trend during the Pliocene followed by a prograding-aggrading trend during the Pleistocene (after $2.6 \mathrm{Ma}$ ). Note that the vertical scale units are respectively metres in $A$ and secondes (twtt) in B. This explains the relative differences in unit thicknesses, in particular for the pre-Messinian Miocene unit. See also seismic lines corresponding to the black boxes S1 \& S2 in the supplementary information. 


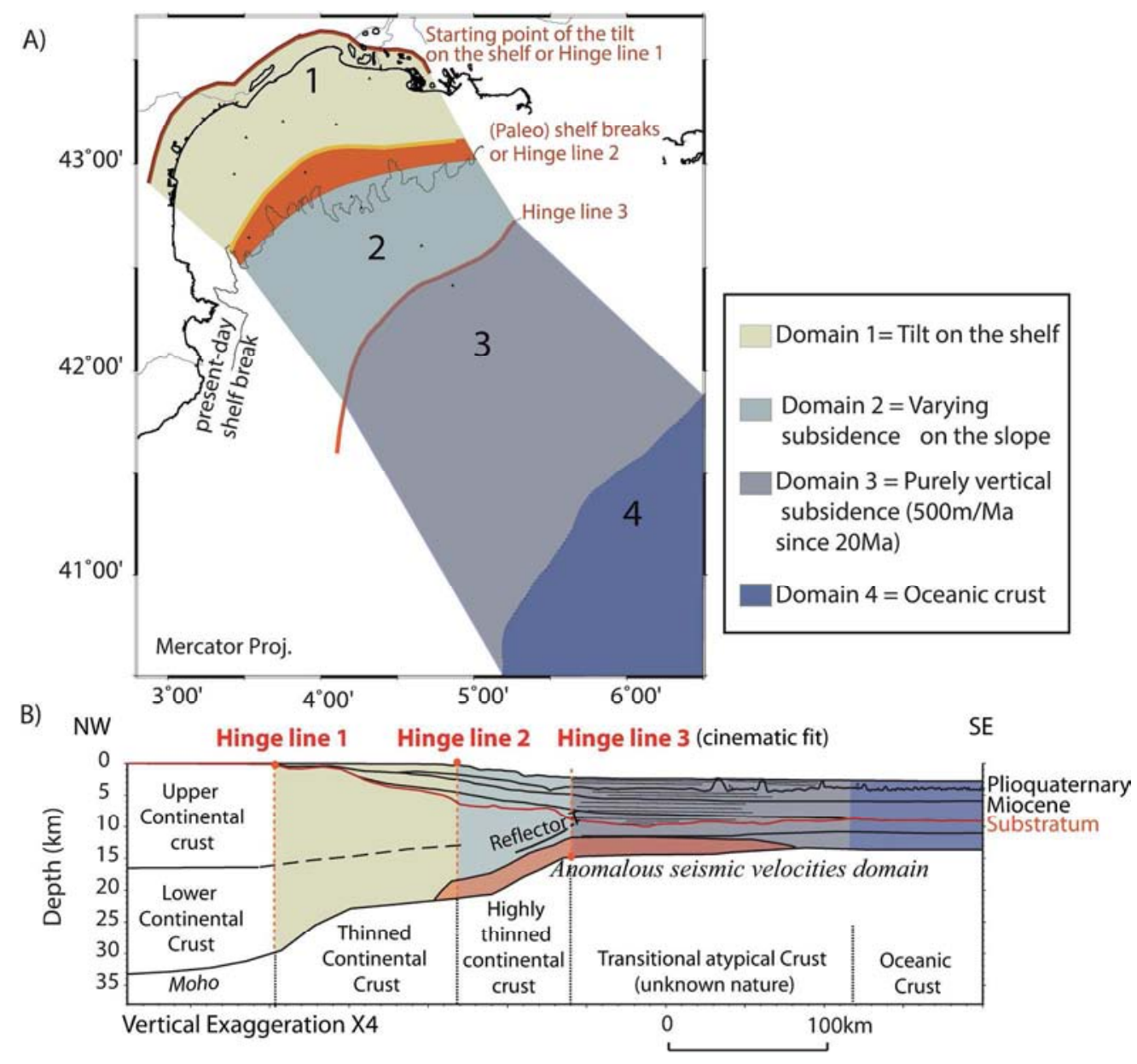

$208 \times 215 \mathrm{~mm}(300 \times 300$ DPI $)$ 
What follows is supplementary material, which will be made available online but will not appear in the print version. 


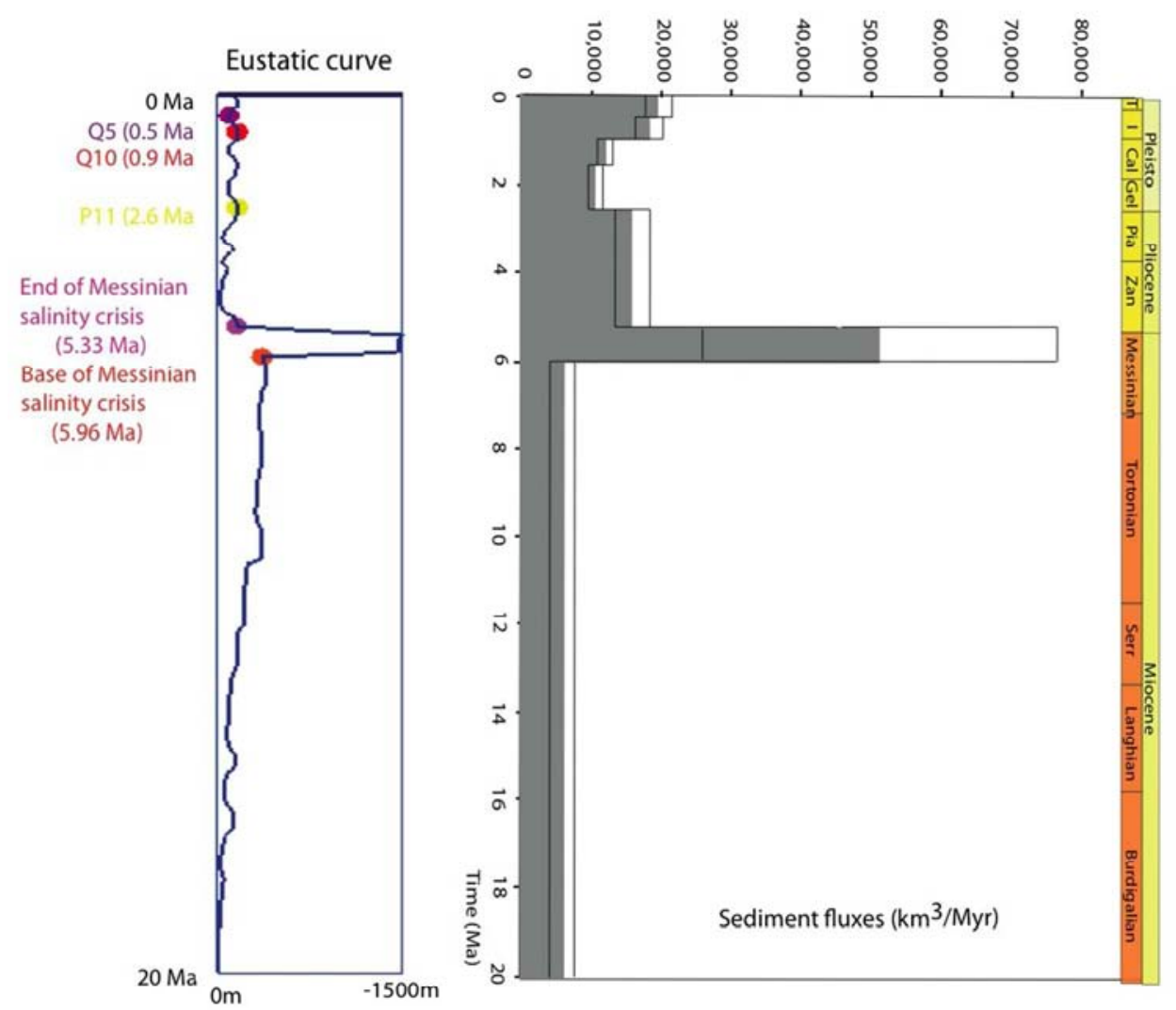

Figure S1 (Supplementary Information). Major input parameters into the model (subsidence excluded): evolution of eustatic curve and sediment supply

Major input parameters (evolution of the eustatic curve and sediment supply) for the 3D simulation of postrift filling of the Provence basin. The simulation was run over the last $20 \mathrm{Ma}$ with a $0.1 \mathrm{Ma}$ time-step. The basin is defined as a rectangular area $(250 \times 400 \mathrm{~km})$ and the initial basement at $20 \mathrm{Ma}$ is flat with a paleobathymetry around $+100 \mathrm{~m}$ (cf text for explanation). 


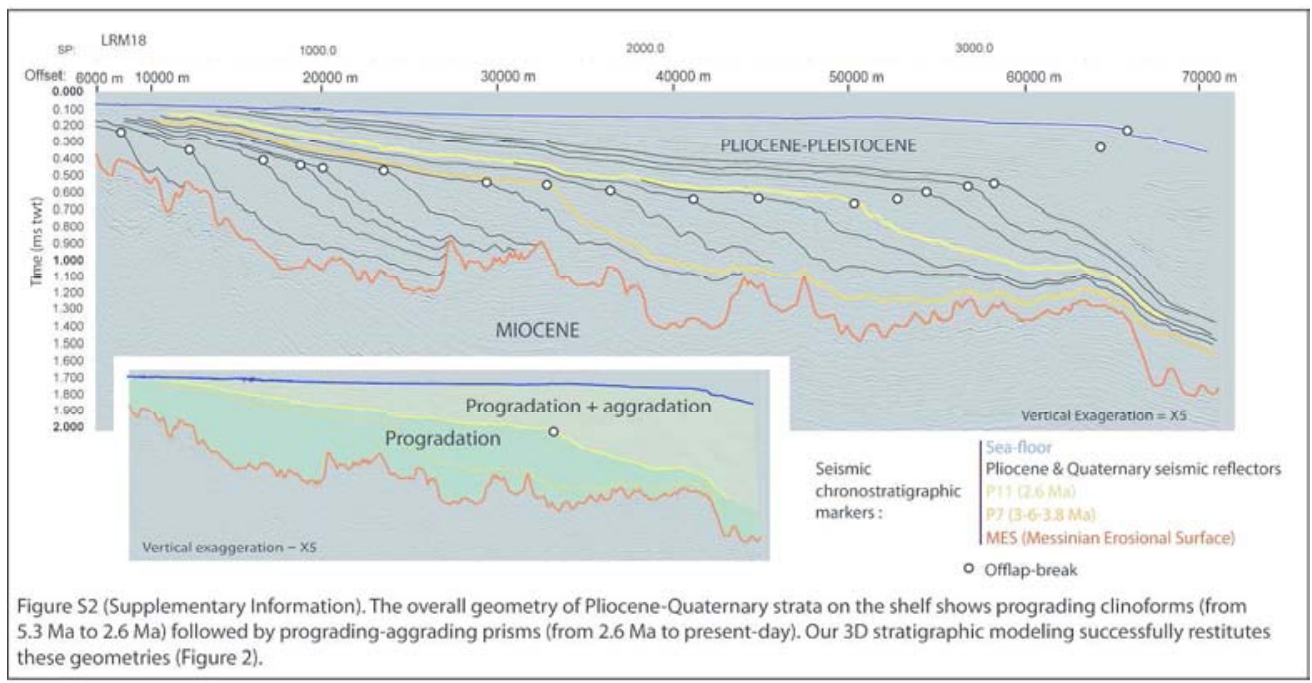

Interpretated LRM18 seismic reflection profile. The offlap-breaks are represented with white dots; Inset: the overall geometry of Pliocene-Quaternary strata shows prograding clinoforms (or prisms) with a clear geometrical change in the Late Pliocene to Quaternary clinoforms (after yellow horizon p11), from essentially prograding (green) to prograding-aggrading (yellow). Leroux et al., 2014.

$1080 \times 565 \mathrm{~mm}(72 \times 72 \mathrm{DPI})$ 


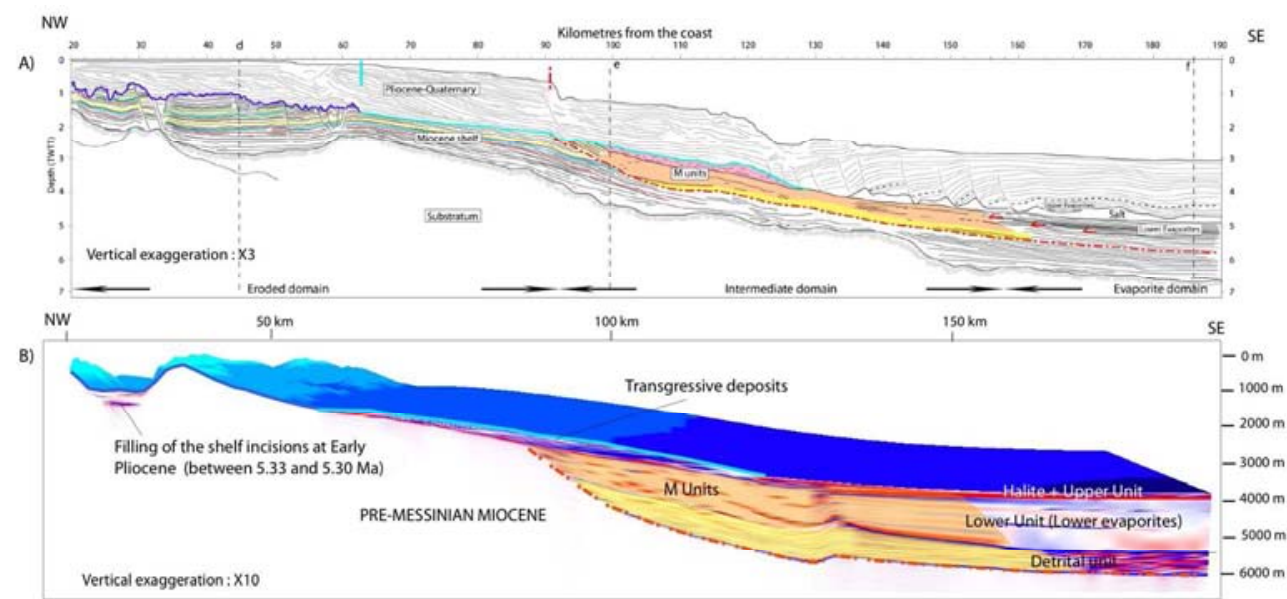

Figure S3 (Supplementary Information). Comparison between (A) a regional seismic profile and (B) the same seismic profile extracted by Dionisos from our Messinian modelling. Our 3D modelling successfully restitutes the sediment geometries during the Messinian Salinity Crisis.

Comparison between (A) a regional seismic profile from (Bache, 2009) and (B) the same seismic profile extracted by Dionisos from our Messinian modelling. On this synthetic seismic line, the impedance constrasts (in red and blue scale) highlight the same discontinuities we have observed on the seismic profile A. The final simulated present-day topography (in blue-scale as function of the depth) is surimposed on the synthetic section. 